\title{
Electrochemical Behaviour of 4-Tertbutylcyclohexanone Semicarbazone and its Co(II) Complex
}

\author{
Lakshmi Meena, Preeti Choudhary, A.K. Varshney and S. Varshney* \\ Department of Chemistry, University of Rajasthan, Jaipur-302004, India
}

Received August 11, 2017; accepted January 15, 2018

\begin{abstract}
The electrochemical behaviour of 4-tertbutylcyclohexanone semicarbazone (TBCHSC) and its $\mathrm{Co}$ (II) complex was investigated by a glassy carbon electrode, cyclic voltammetry technique. Semicarbazone synthesized from the condensation of 4tertbutylcyclohexanone and semicarbazide hydrochloride (1:1 molar ratio) was further treated with cobalt(II) acetate (2:1 molar ratio), to form the $\mathrm{Co}$ (II)-semicarbazone complex. The semicarbazone was studied in buffer solutions (Britton-Robinson universal buffer and phosphate buffer), with a $\mathrm{pH}$ in the range of 3 to 11 . The reduction process was found to be irreversible and diffusion controlled, for both semicarbazone and its $\mathrm{Co}$ (II) complex. The effects of change on the sweep rate, concentration, $\mathrm{pH}$ and solvent were evaluated. The semicarbazone reduction mechanism was suggested on the basis of the obtained results. Kinetic parameters, such as charge transfer coefficient $\left(\alpha_{n}\right)$, diffusion coefficient $\left(\mathrm{D}_{0}{ }^{1 / 2}\right)$, and rate constant $\left(\mathrm{k}_{\mathrm{f}, \mathrm{h}}^{\circ}\right)$, were calculated from cyclic voltammetric measurements. Semicarbazone and its $\mathrm{Co}$ (II) complex were tested against bacterial and fungal species. The metal complex had higher activity than the free ligand.
\end{abstract}

Keywords: 4-tertbutylcyclohexanone semicarbazone, $\mathrm{Co}(\mathrm{II})$ complex, cyclic voltammetry, kinetic parameters, antimicrobial activities.

\section{Introduction}

The electrochemical technique is one of the greener, more economic, specific and selective approaches [1-2]. Electrochemical reactions are most often studied with standard three electrode techniques, such as cyclic voltammetry, polarography, etc. Cyclic voltammetry has gained extensive use in providing information about the reduction, oxidation and formation of intermediates, and also on the reversible nature of the electrode transfer processes. Cyclic voltammograms provide valuable information regarding electrode processes [3-4]. Semicarbazones are amongst the most widely studied nitrogen and oxygen/sulphur donor ligands. They have been a subject of interest in recent decades, due to their biological activity, good complexing properties and analytical applications [5-9]. Systematic perusal of earlier literature reveals that,

\footnotetext{
* Corresponding author. E-mail address: saritavarshney@rediffmail.com, drsaritavarshney@gmail.com
} 
in spite of the variegated importance associated to semicarbazones compounds, relatively few reports exist on their electrochemical behaviour [10-16]. Hence, efforts have been made to undertake cyclic voltammetric studies on 4tertbutylcyclohexanone semicarbazone (TBCHSC). In this process, TBCHSC's imine group $(-\mathrm{C}=\mathrm{N}-)$ has been reduced into the amine group $\left(-\mathrm{CH}-\mathrm{NH}_{2}\right)$, in a protic solvent such as $\mathrm{CH}_{3} \mathrm{OH}$, by the transfer of $4 \mathrm{e}^{-}$[17-18]. In this paper synthesis, spectral analysis, cyclic voltammetric and antimicrobial activity studies of TBCHSC and its Co(II) complex have been carried out.

\section{Experimental}

All employed chemicals were of analytical grade. Methanol was freshly distilled prior to use. IR spectra were acquired using an A-8400 S, Shimadzu Spectrophotometer model, and KBr optics.

\section{Ligand synthesis}

Semicarbazone was synthesized mixing 4-tertbutylcyclohexanone, semicarbazide hydrochloride and sodium acetate trihydrated (equimolar ratio) in methanol (Scheme I). TBCHSC was synthesized by the standard procedure, as available in the literature [19-20].

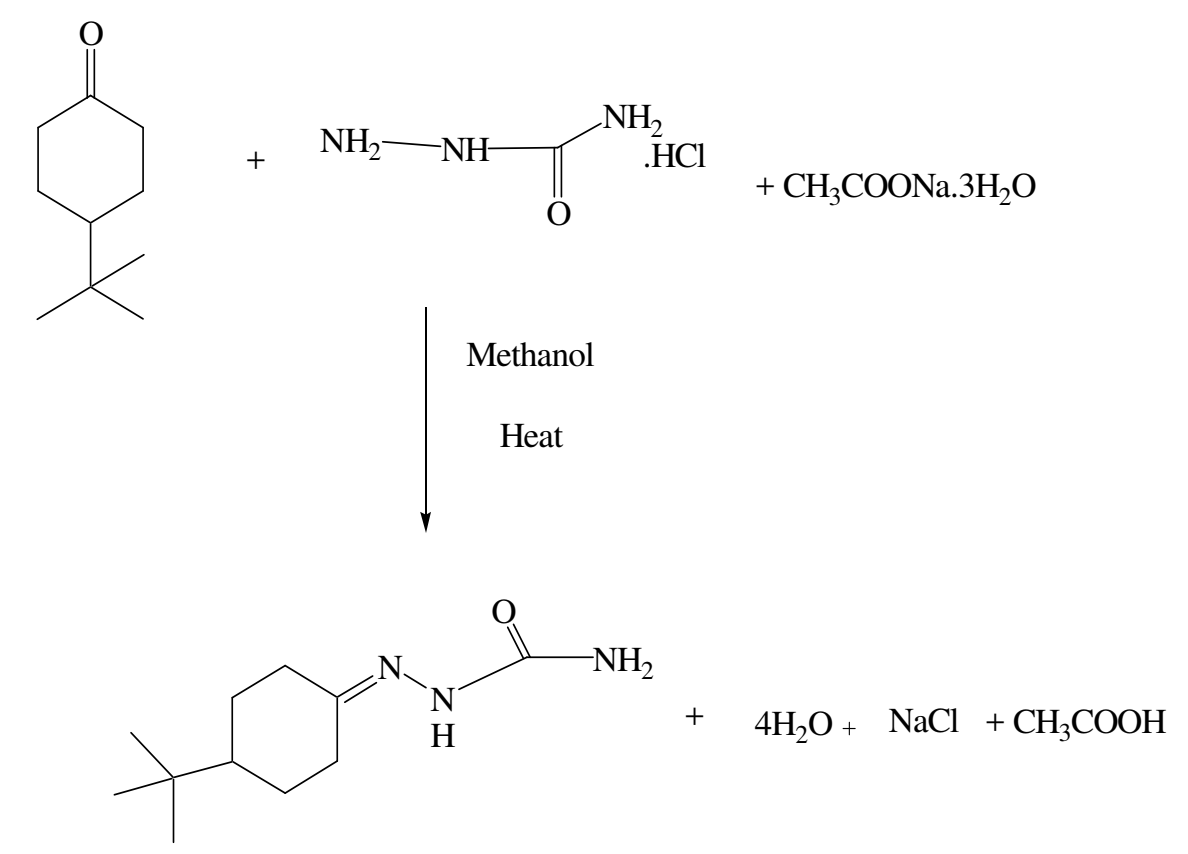

Scheme I. Synthesis of 4-tertbutylcyclohexanone semicarbazone.

\section{Synthesis of the complex}

The TBCHSC cobalt complex was synthesized in a methanolic solution of TBCHSC, by mixing it with a methanolic solution of Co(II) acetate (2:1 molar ratio), refluxing the mixture for 5 hours, and drying it in vacuum over fused $\mathrm{CaCl} 2$ (Scheme II). 


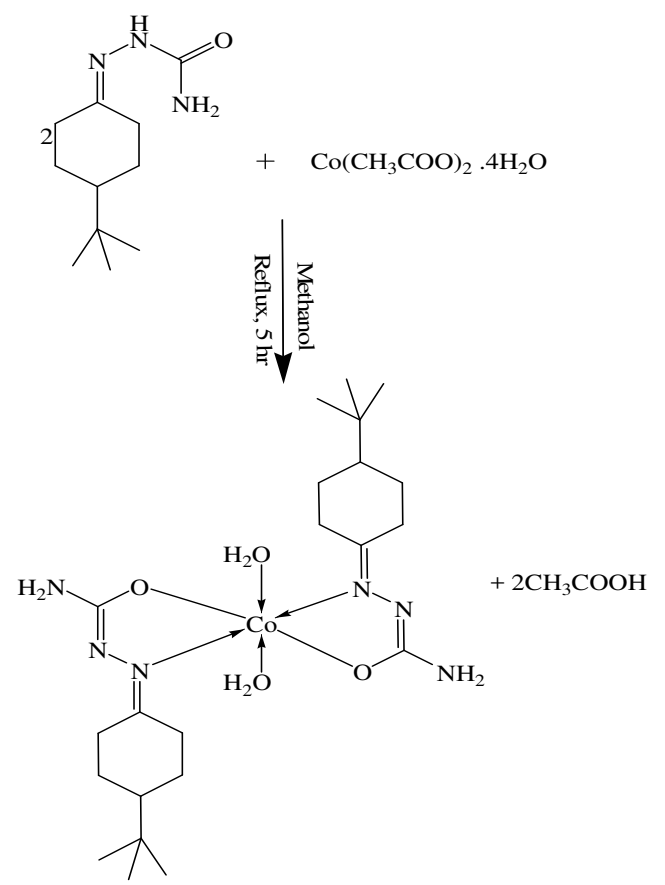

Scheme II. Synthesis of the TBCHSC Co(II) complex.

\section{Cyclic voltammetric study of TBCHSC and its Co(II) complex}

Semicarbazone's stock solutions $\left(1 \times 10^{-2} \mathrm{M}\right)$ in dimethylformamide $(A R)$ and methanol were prepared. Britton-Robinson and phosphate buffers were prepared in double distilled water. In the typical cyclic voltammetric experiment, a reaction mixture consists of a compound solution, solvent (the minimum volume necessary to keep the compound in the solution) and a buffer solution (keeping the overall volume constant at $10 \mathrm{~mL}$ ).

The stock solution of the complex was prepared in alcohol and DMF. $1 \mathrm{M}$ $\mathrm{NaClO}_{4}$ was prepared in double distilled water, and used as supporting electrolyte. The working solution was prepared by taking $1 \mathrm{~mL}$ of the stock solution $(0.01 \mathrm{M})$ of the complex and $1 \mathrm{~mL}$ of the supporting electrolyte solution $\left(1 \mathrm{M} \mathrm{NaClO}_{4}\right.$ ). The final solution was made up to $10.0 \mathrm{~mL}$, by adding alcohol or DMF to get $1 \mathrm{mM}$ concentration of the experimental solution.

A stream of nitrogen gas was passed over the reaction mixture. The three electrodes (glassy carbon electrode-working electrode, $\mathrm{Ag} / \mathrm{AgCl}$-reference electrode and a $\mathrm{Pt}$ wire-auxiliary electrode) were connected to the electrochemical cell. Required scan rates, current sensitivity, initial potential and final potential were applied, and the resulting current was measured as a function of the applied potential.

The electrochemical reduction behaviour of the synthesized TBCHSC was studied on a glassy carbon electrode in $\mathrm{DMF}$ and $\mathrm{CH}_{3} \mathrm{OH}$ media, using phosphate and $\mathrm{B}-\mathrm{R}$ buffers, at various sweep rates, $\mathrm{pH}$ values and electroactive species concentrations. The compound exhibited one irreversible reduction peak in the cathodic direction. Thus, kinetic parameters, such as charge-transfer coefficient $\left(\alpha_{\mathrm{n}}\right)$, diffusion coefficient $\left(\mathrm{D}_{0}{ }^{1 / 2}\right)$ and rate constant $\left(\mathrm{K}_{\mathrm{f}, \mathrm{h}}^{0}\right)$ were calculated for an irreversible and diffusion controlled reduction, by using the following equations [21-24]: 


$$
\begin{gathered}
\left|E_{p}-E_{p / 2}\right|=\frac{1.857 R T}{\alpha_{n} F}=\left(\frac{47.7}{\alpha_{n}}\right) m V \\
I_{P}=3.01 \times 10^{5} n\left(\alpha_{n}\right)^{1 / 2} A C D_{0}^{1 / 2} v^{1 / 2} \\
E_{P}=-\frac{R T}{\alpha_{n} F}\left[0.78+\ln \left(\frac{D_{0}^{1 / 2}}{k_{f, h}^{\circ}}\right)+\ln \left(\frac{\alpha_{n} F v}{R T}\right)^{1 / 2}\right]
\end{gathered}
$$

Most of the cyclic voltammograms were recorded with an initial potential (Ei) value of +500 and a switching potential value (Es) of $-1100 \mathrm{mV}$ for semicarbazone. For the complex, the Ei value was +500 and the Es value was $-1000 \mathrm{mV}$, at the scan rates of $50-250 \mathrm{mV} / \mathrm{sec}$. The various parameters employed to evaluate the electrochemical reversibility are listed in Tables 1 to 6 .

\section{Antimicrobial studies}

In vitro antibacterial activity of the compounds was studied against gram positive and gram negative bacterial strains, by the agar well diffusion method. Mueller Hinton agar no. 2 was used as bacteriological medium. The antifungal activity of the experimental compounds was investigated by the agar well diffusion method. The yeasts and saprophytic fungi were sub cultured onto Sabouraud's dextrose agar (SDA) (Merck, Germany). The activity index was calculated by the standard zone of inhibition [25-28].

\section{Results and discussion}

\section{Cyclic voltammetry studies}

The cyclic voltammetric results for semicarbazone are given in Tables 1 to 4, and its voltammograms are depicted in Figs. 1 to 4.

Table 1. Effect of the sweep rate on the voltammetric parameters of $1 \mathrm{mM} 4$ -

\begin{tabular}{|c|c|c|c|c|c|c|c|c|}
\hline pH & $\begin{array}{c}v \\
\left(\mathbf{m V s}^{-1)}\right.\end{array}$ & $\begin{array}{c}\boldsymbol{E}_{\boldsymbol{p} c} \\
(\mathbf{m V})\end{array}$ & $\begin{array}{c}I_{p c} \\
(\mu \mathrm{A})\end{array}$ & $\begin{array}{l}\boldsymbol{E}_{p / 2} \\
(\mathbf{m V})\end{array}$ & $\boldsymbol{I}_{p c} / \boldsymbol{v}^{1 / 2}$ & $\alpha_{n}$ & $\begin{array}{c}D_{0}{ }^{1 / 2} \mathbf{x 1 0}^{3} \\
\left(\mathrm{~cm}^{2} \mathrm{~s}^{-1}\right)\end{array}$ & $\begin{array}{c}k_{f, h}^{\circ} \\
\left(\mathrm{cm}^{-1} \mathbf{s}^{-1}\right)\end{array}$ \\
\hline \multirow{5}{*}{5.8} & 50 & -475.81 & 09.10 & -149.28 & 1.30 & 0.1460 & 10.59762 & $8.22684 \times 10^{-4}$ \\
\hline & 100 & -510.93 & 17.18 & -173.42 & 1.84 & 0.1413 & 14.39066 & $1.39865 \times 10^{-3}$ \\
\hline & 150 & -518.79 & 22.50 & -188.78 & 1.89 & 0.1445 & 15.20863 & $1.64316 \times 10^{-3}$ \\
\hline & 200 & -544.83 & 26.15 & -265.04 & 1.85 & 0.1704 & 14.09507 & $9.51096 \times 10^{-4}$ \\
\hline & 250 & -572.17 & 29.60 & -300.03 & 1.87 & 0.1752 & 14.07352 & $8.06756 \times 10^{-4}$ \\
\hline \multirow{5}{*}{7.0} & 50 & -540.76 & 14.32 & -230.72 & 2.03 & 0.1538 & 16.25011 & $7.59562 \times 10^{-4}$ \\
\hline & 100 & -590.32 & 21.47 & -270.27 & 2.14 & 0.1490 & 17.50362 & $9.45156 \times 10^{-4}$ \\
\hline & 150 & -606.08 & 27.92 & -294.62 & 2.28 & 0.1531 & 18.33405 & $1.01787 \times 10^{-3}$ \\
\hline & 200 & -617.67 & 29.89 & -321.50 & 2.11 & 0.1610 & 16.57592 & $8.40880 \times 10^{-4}$ \\
\hline & 250 & -621.05 & 34.19 & -350.16 & 2.16 & 0.1760 & 16.21889 & $6.54659 \times 10^{-4}$ \\
\hline \multirow{5}{*}{8.0} & 50 & -706.22 & 13.79 & -369.99 & 1.95 & 0.1418 & 16.29719 & $3.77331 \times 10^{-4}$ \\
\hline & 100 & -718.35 & 20.60 & -372.10 & 2.00 & 0.1377 & 17.46839 & $5.91325 \times 10^{-4}$ \\
\hline & 150 & -747.26 & 26.72 & -405.96 & 2.18 & 0.1397 & 18.36735 & $6.19647 \times 10^{-4}$ \\
\hline & 200 & -758.08 & 27.95 & -422.24 & 1.98 & 0.1420 & 16.50532 & $5.71478 \times 10^{-4}$ \\
\hline & 250 & -799.14 & 39.20 & -426.46 & 2.48 & 0.1279 & 21.81098 & $9.88632 \times 10^{-4}$ \\
\hline
\end{tabular}
tertbutylcyclohexanone semicarbazone in a $\mathrm{CH}_{3} \mathrm{OH}^{-}$phosphate buffer, at different $\mathrm{pHs}$ (5.8, 7 and 8). 
Table 2. Effect of the sweep rate on the voltammetric parameters of 4tertbutylcyclohexanone semicarbazone in a $\mathrm{CH}_{3} \mathrm{OH}-\mathrm{BR}$ buffer at different $\mathrm{pH}(3,5$ and 9).

\begin{tabular}{|c|c|c|c|c|c|c|c|c|}
\hline $\mathbf{p H}$ & $\begin{array}{l}N \mathrm{~m} \\
\mathrm{Vs}^{-1}\end{array}$ & $\begin{array}{c}E_{p c} \\
(\mathbf{m V})\end{array}$ & $\begin{array}{c}I_{p c} \\
(\boldsymbol{\mu} \mathbf{A})\end{array}$ & $\begin{array}{c}E_{p / 2} \\
(\mathrm{mV})\end{array}$ & $I_{p c} / v^{1 / 2}$ & $\alpha_{n}$ & $\begin{array}{c}D_{0}{ }^{1 / 2} \times 10^{3} \\
\left(\mathrm{~cm}^{2} \mathrm{~s}^{-1)}\right.\end{array}$ & $\begin{array}{c}k_{f, h}^{\circ} \\
\left(\mathrm{cm}^{\circ} \mathrm{s}^{-1}\right)\end{array}$ \\
\hline \multirow{5}{*}{3.0} & 50 & -371.53 & 08.127 & -133.70 & 1.1490 & 0.20056 & 8.077375 & $6.04479 \times 10^{-4}$ \\
\hline & 100 & -408.79 & 14.72 & -168.70 & 1.4720 & 0.19867 & 10.39415 & $8.43410 \times 10^{-4}$ \\
\hline & 150 & -414.83 & 16.53 & -190.20 & 1.3500 & 0.21234 & 9.218462 & $7.24723 \times 10^{-4}$ \\
\hline & 200 & -445.85 & 23.13 & -223.42 & 1.6357 & 0.21444 & 11.11616 & $7.56498 \times 10^{-4}$ \\
\hline & 250 & -464.88 & 26.42 & -237.43 & 1.6736 & 0.20971 & 11.48419 & $8.03030 \times 10^{-4}$ \\
\hline \multirow{5}{*}{5.0} & 50 & -664.84 & 19.77 & -322.14 & 2.7970 & 0.13919 & 23.59254 & $7.28920 \times 10^{-4}$ \\
\hline & 100 & -713.15 & 24.84 & -435.05 & 2.4844 & 0.17152 & 18.88041 & $2.87094 \times 10^{-4}$ \\
\hline & 150 & -765.63 & 33.30 & -443.20 & 2.7210 & 0.14794 & 22.25396 & $5.47605 \times 10^{-4}$ \\
\hline & 200 & -782.34 & 39.62 & -463.81 & 2.8019 & 0.14975 & 22.78574 & $5.59838 \times 10^{-4}$ \\
\hline & 250 & -788.49 & 46.30 & -444.24 & 2.9289 & 0.13856 & 24.76309 & $8.90162 \times 10^{-4}$ \\
\hline \multirow{5}{*}{9.0} & 50 & -859.26 & 12.78 & -515.48 & 1.8079 & 0.13875 & 15.27371 & $1.66648 \times 10^{-4}$ \\
\hline & 100 & -974.09 & 18.44 & -600.11 & 1.8440 & 0.12754 & 16.25118 & $1.97765 \times 10^{-4}$ \\
\hline & 150 & -995.80 & 24.84 & -564.61 & 2.0290 & 0.11062 & 19.19271 & $4.61022 \times 10^{-4}$ \\
\hline & 200 & -1030.6 & 31.54 & -550.54 & 2.2300 & 0.09936 & 22.26835 & $7.91779 \times 10^{-4}$ \\
\hline & 250 & -1082.4 & 35.44 & -553.51 & 2.2400 & 0.09018 & 23.49177 & $1.07196 \times 10^{-3}$ \\
\hline
\end{tabular}

Table 3. Effect of the sweep rate on the voltammetric parameters of $1 \mathrm{mM} 4$ tertbutylcyclohexanone semicarbazone in a DMF-phosphate buffer at different $\mathrm{pHs}$ (5.8, 7 and 8).

\begin{tabular}{|c|c|c|c|c|c|c|c|c|}
\hline pH & $\begin{array}{c}v \\
\left(m V s^{-1}\right)\end{array}$ & $\begin{array}{c}E_{p c} \\
(\mathbf{m V})\end{array}$ & $\begin{array}{c}I_{p c} \\
(\boldsymbol{\mu A})\end{array}$ & $\begin{array}{c}E_{p / 2} \\
(\mathrm{mV})\end{array}$ & $I_{p c} / v^{1 / 2}$ & $\alpha_{n}$ & $\begin{array}{c}D_{0}^{1 / 2} \times 10^{3} \\
\left(\mathrm{~cm}^{2} \mathrm{~s}^{-1}\right)\end{array}$ & $\begin{array}{c}k_{f, h}^{\circ} \\
\left(\mathrm{cm}^{-s^{-1}}\right)\end{array}$ \\
\hline \multirow{5}{*}{5.8} & 50 & -772.87 & 06.10 & -447.81 & 0.86 & 0.14674 & 7.087903 & $9.97320 \times 10^{-5}$ \\
\hline & 100 & -784.32 & 09.81 & -450.50 & 0.98 & 0.14289 & 8.167991 & $1.68979 \times 10^{-4}$ \\
\hline & 150 & -798.88 & 13.09 & -459.12 & 1.06 & 0.14039 & 8.977866 & $2.24739 \times 10^{-4}$ \\
\hline & 200 & -828.11 & 20.27 & -483.26 & 1.43 & 0.13832 & 12.12951 & $3.17084 \times 10^{-4}$ \\
\hline & 250 & -844.57 & 24.20 & -504.62 & 1.53 & 0.14031 & 12.86021 & $3.24495 \times 10^{-4}$ \\
\hline \multirow{5}{*}{7.0} & 50 & -742.01 & 07.26 & -511.07 & 1.03 & 0.20654 & 7.110444 & $2.51440 \times 10^{-5}$ \\
\hline & 100 & -818.78 & 18.68 & -510.42 & 1.80 & 0.15469 & 14.95154 & $1.82343 \times 10^{-4}$ \\
\hline & 150 & -834.24 & 22.13 & -539.55 & 1.81 & 0.16187 & 14.13513 & $1.55824 \times 10^{-4}$ \\
\hline & 200 & -844.10 & 25.44 & -556.45 & 1.80 & 0.16582 & 13.90371 & $1.47827 \times 10^{-4}$ \\
\hline & 250 & -868.79 & 31.90 & -588.10 & 2.02 & 0.16993 & 15.40398 & $1.37520 \times 10^{-4}$ \\
\hline \multirow{5}{*}{8.0} & 50 & -789.39 & 07.12 & -558.03 & 1.00 & 0.20617 & 6.988405 & $1.70580 \times 10^{-5}$ \\
\hline & 100 & -827.50 & 10.28 & -604.03 & 1.02 & 0.21345 & 7.007899 & $1.43350 \times 10^{-5}$ \\
\hline & 150 & -843.98 & 13.44 & -639.74 & 1.18 & 0.23355 & 7.147319 & $8.43400 \times 10^{-6}$ \\
\hline & 200 & -854.64 & 17.13 & -655.26 & 1.21 & 0.23924 & 7.79786 & $8.07600 \times 10^{-6}$ \\
\hline & 250 & -881.24 & 18.08 & -685.22 & 1.11 & 0.24334 & 7.296539 & $5.77700 \times 10^{-6}$ \\
\hline
\end{tabular}

Table 4. Effect of the concentration on the cathodic peak potential and peak current for 4-tertbutylcyclohexanone semicarbazone $(\mathrm{mM})$ in an alcohol phosphate buffer at $\mathrm{pH}$ 5.8 .

\begin{tabular}{|c|c|c|c|c|c|c|c|c|}
\hline \multirow{3}{*}{$\begin{array}{c}v \\
\mathrm{mV} / \mathrm{s}\end{array}$} & \multicolumn{8}{|c|}{$\begin{array}{c}\text { Concentration of 4-tertbutylcyclohexanone semicarbazone (mM) } \\
\text { in an alcohol phosphate buffer at pH } 5.8\end{array}$} \\
\hline & \multicolumn{2}{|c|}{$1 \mathrm{mM}$} & \multicolumn{2}{|c|}{$2 \mathrm{mM}$} & \multicolumn{2}{|c|}{$3 \mathrm{mM}$} & \multicolumn{2}{|c|}{$4 \mathrm{mM}$} \\
\hline & $\begin{array}{c}\mathbf{E}_{\mathbf{p}, \mathbf{c}} \\
(\mathbf{m V})\end{array}$ & $\begin{array}{c}\mathbf{I}_{\mathbf{p}, \mathbf{c}} \\
(\boldsymbol{\mu A})\end{array}$ & $\begin{array}{c}\mathbf{E}_{\mathbf{p}, \mathbf{c}} \\
(\mathbf{m V V})\end{array}$ & $\begin{array}{c}\mathbf{I}_{\mathbf{p}, \mathbf{c}} \\
(\boldsymbol{\mu A})\end{array}$ & $\begin{array}{c}\mathbf{E}_{\mathbf{p}, \mathbf{c}} \\
(\mathbf{m V})\end{array}$ & $\begin{array}{c}\mathbf{I}_{\mathbf{p}, \mathbf{c}} \\
(\boldsymbol{\mu A})\end{array}$ & $\begin{array}{c}\mathbf{E}_{\mathbf{p}, \mathbf{c}} \\
(\mathbf{m V})\end{array}$ & $\begin{array}{c}\mathbf{I}_{\mathbf{p}, \mathbf{c}} \\
(\boldsymbol{\mu A})\end{array}$ \\
\hline 50 & -475.810 & 09.19 & -535.50 & 14.211 & -630.78 & 09.61 & -680.87 & 11.18 \\
\hline 100 & -510.92 & 17.18 & -590.32 & 21.47 & -668.45 & 23.43 & -688.88 & 18.79 \\
\hline 150 & -518.94 & 22.50 & -634.18 & 27.55 & -710.00 & 26.00 & -729.46 & 26.50 \\
\hline 200 & -544.833 & 26.15 & -658.58 & 39.26 & -739.83 & 37.86 & -797.71 & 33.58 \\
\hline 250 & -572.173 & 29.61 & -676.56 & 45.08 & -744.05 & 46.11 & -903.633 & 38.14 \\
\hline
\end{tabular}




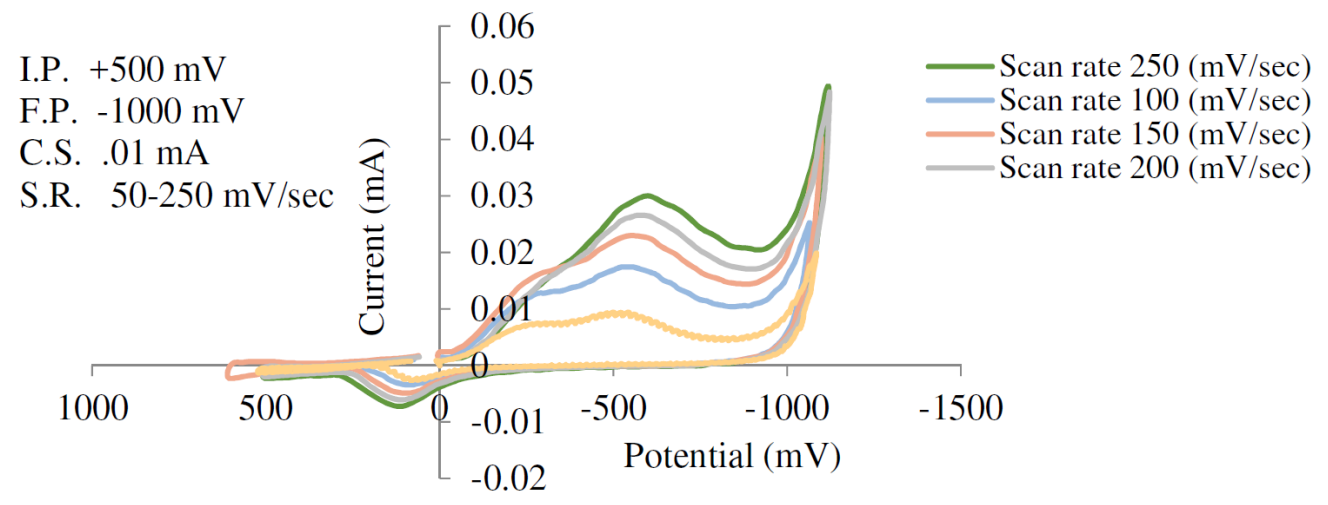

Figure 1. TBCHSC cyclic voltammograms in a methanolic medium containing a phosphate buffer ( $\mathrm{pH}$ 5.8).

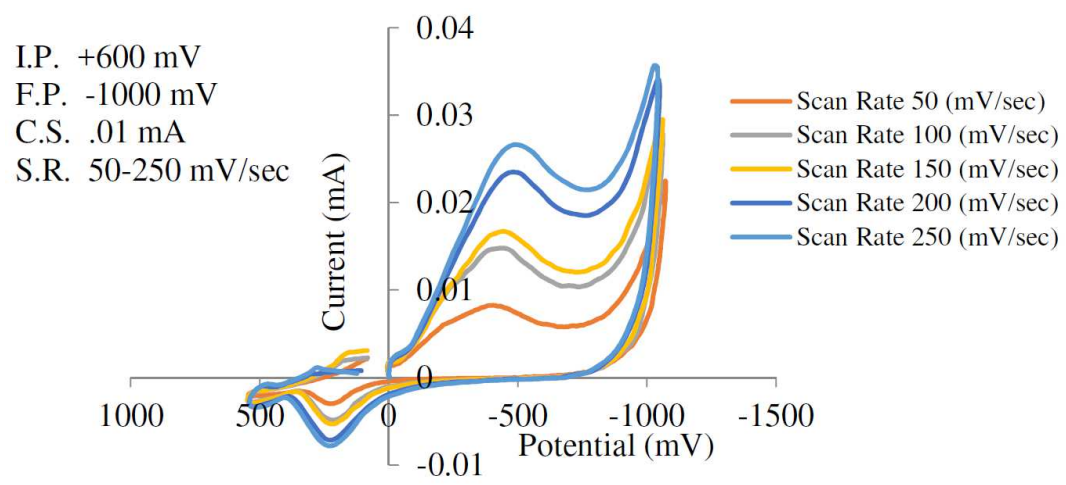

Figure 2. TBCHSC cyclic voltammograms in a methanolic medium containing a BR buffer ( $\mathrm{pH} 3)$.

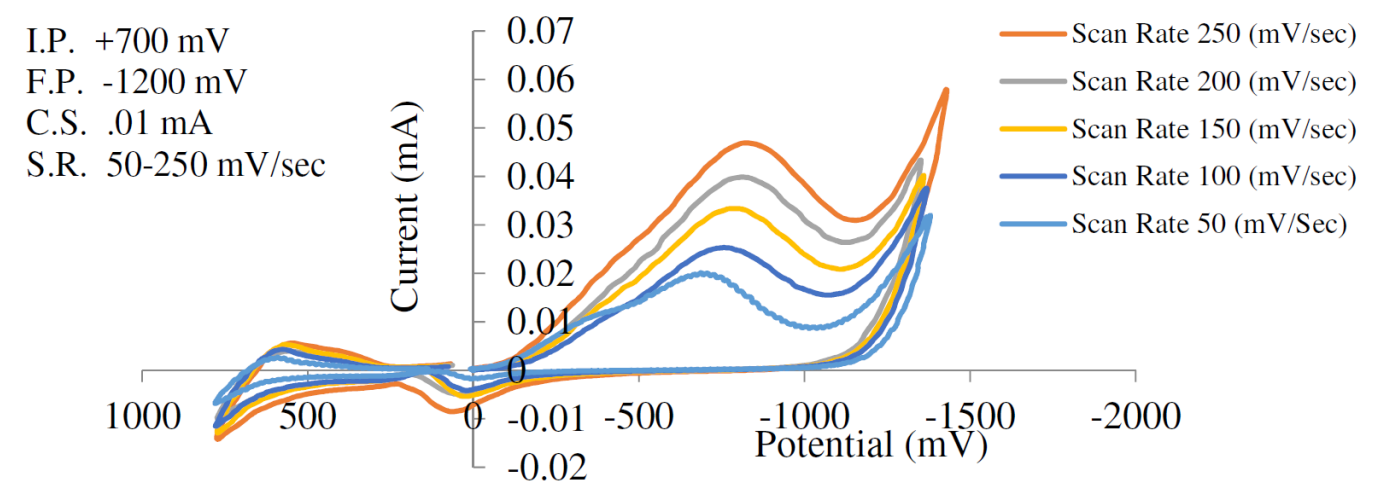

Figure 3. TBCHSC cyclic voltammograms in a methanolic medium containing a BR buffer ( $\mathrm{pH}$ 5).

The cyclic voltammetric results for the complex are presented in Tables 5 to 6 , and its voltammograms are displayed in Figs. 5 to 6. 


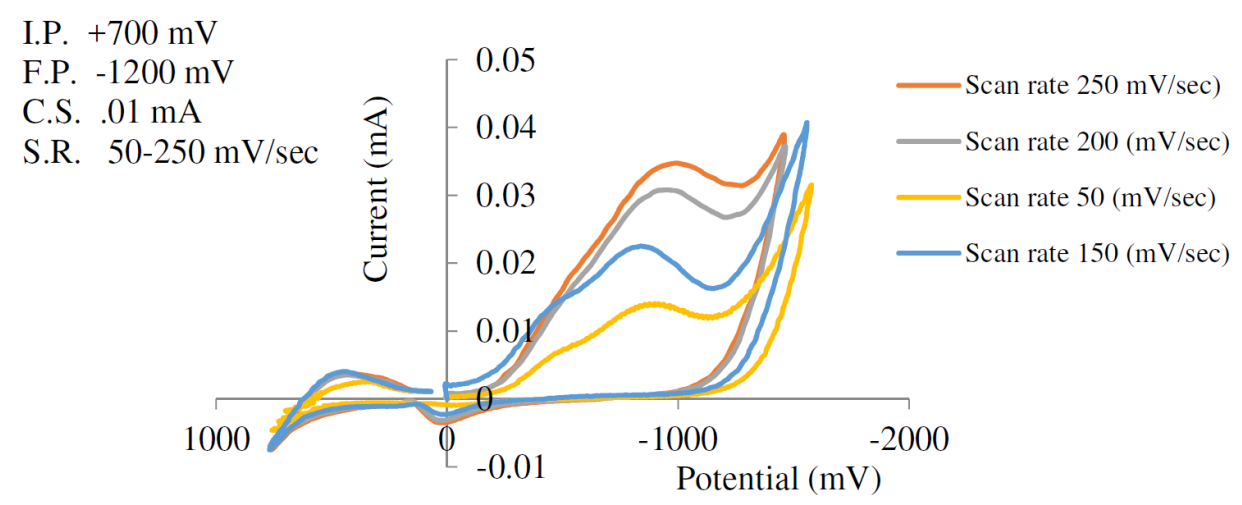

Figure 4. TBCHSC cyclic voltammograms in a DMF medium containing a phosphate buffer ( $\mathrm{pH} 7)$.

Table 5. Effect of the sweep rate on the voltammetric parameters of the Co(II) complex of 4-tertbutylcyclohexanone semicarbazone in methanol- $\mathrm{NaClO}_{4}$, at different concentrations.

\begin{tabular}{|c|c|c|c|c|c|}
\hline $\begin{array}{c}\text { Complex } \\
\text { conc. }\end{array}$ & $\begin{array}{c}v \\
\left(\mathbf{m V s}^{-1}\right)\end{array}$ & $\begin{array}{c}E_{p c} \\
(\mathbf{m V})\end{array}$ & $\begin{array}{l}\boldsymbol{E}_{p 1 / 2} \\
(\mathrm{mV})\end{array}$ & $\begin{array}{c}I_{p, c} \\
(\mu \mathbf{A})\end{array}$ & $\boldsymbol{I}_{p, c} / \mathbf{v}^{1 / 2}$ \\
\hline \multirow{5}{*}{$1 \mathrm{mM}$} & 50 & -688.29 & -592.46 & 09.18 & 1.298 \\
\hline & 100 & -745.50 & -624.68 & 11.75 & 1.175 \\
\hline & 150 & -747.50 & -621.84 & 15.70 & 1.282 \\
\hline & 200 & -751.71 & -584.20 & 18.26 & 1.291 \\
\hline & 250 & -781.70 & -642.72 & 22.20 & 1.400 \\
\hline \multirow{5}{*}{$2 \mathrm{mM}$} & 50 & -704.03 & -617.43 & 12.58 & 1.779 \\
\hline & 100 & -741.89 & -641.89 & 15.39 & 1.539 \\
\hline & 150 & -748.12 & -635.61 & 20.21 & 1.650 \\
\hline & 200 & -765.01 & -647.71 & 26.51 & 1.874 \\
\hline & 250 & -793.40 & -652.67 & 30.60 & 1.935 \\
\hline \multirow{5}{*}{$3 \mathrm{mM}$} & 50 & -711.57 & -638.57 & 16.84 & 2.381 \\
\hline & 100 & -732.58 & -646.73 & 20.10 & 2.010 \\
\hline & 150 & -756.67 & -653.72 & 26.14 & 2.135 \\
\hline & 200 & -777.15 & -660.05 & 32.86 & 2.323 \\
\hline & 250 & -797.55 & -685.22 & 37.37 & 2.363 \\
\hline \multirow{5}{*}{$4 \mathrm{mM}$} & 50 & -725.58 & -642.37 & 21.35 & 3.019 \\
\hline & 100 & -736.89 & -642.26 & 24.65 & 2.465 \\
\hline & 150 & -757.64 & -650.38 & 31.86 & 2.602 \\
\hline & 200 & -785.86 & -667.38 & 40.80 & 2.885 \\
\hline & 250 & -806.41 & -676.50 & 47.60 & 3.010 \\
\hline
\end{tabular}

Table 6. Effect of the sweep rate on the voltammetric parameters of the Co(II) complex

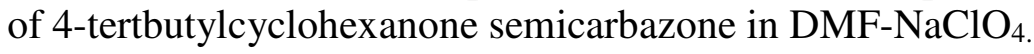

\begin{tabular}{|c|c|c|c|c|c|}
\hline $\begin{array}{c}\text { Complex } \\
\text { conc. }\end{array}$ & $\begin{array}{c}\boldsymbol{v} \\
\left(\mathbf{m V}^{-\mathbf{1}}\right)\end{array}$ & $\begin{array}{c}\boldsymbol{E}_{\boldsymbol{p} \boldsymbol{c}} \\
(\mathbf{m V})\end{array}$ & $\begin{array}{c}\boldsymbol{E} \boldsymbol{p}_{\mathbf{1} / \mathbf{2}} \\
(\mathbf{m V})\end{array}$ & $\begin{array}{c}\boldsymbol{I}_{\boldsymbol{p}, \boldsymbol{c}} \\
(\boldsymbol{\mu} \mathbf{A})\end{array}$ & $\boldsymbol{I}_{p, \boldsymbol{c}} / \mathbf{v}^{\mathbf{1 / 2}}$ \\
\hline \multirow{4}{*}{$1 \mathrm{mM}$} & 50 & -697.82 & -580.39 & 15.63 & 2.210 \\
\cline { 2 - 6 } & 100 & -746.23 & -603.45 & 20.27 & 2.027 \\
\cline { 2 - 6 } & 150 & -749.80 & -607.20 & 28.27 & 2.300 \\
\cline { 2 - 6 } & 200 & -765.19 & -620.63 & 33.00 & 2.330 \\
\cline { 2 - 6 } & 250 & -812.82 & -612.78 & 45.17 & 2.857 \\
\hline
\end{tabular}




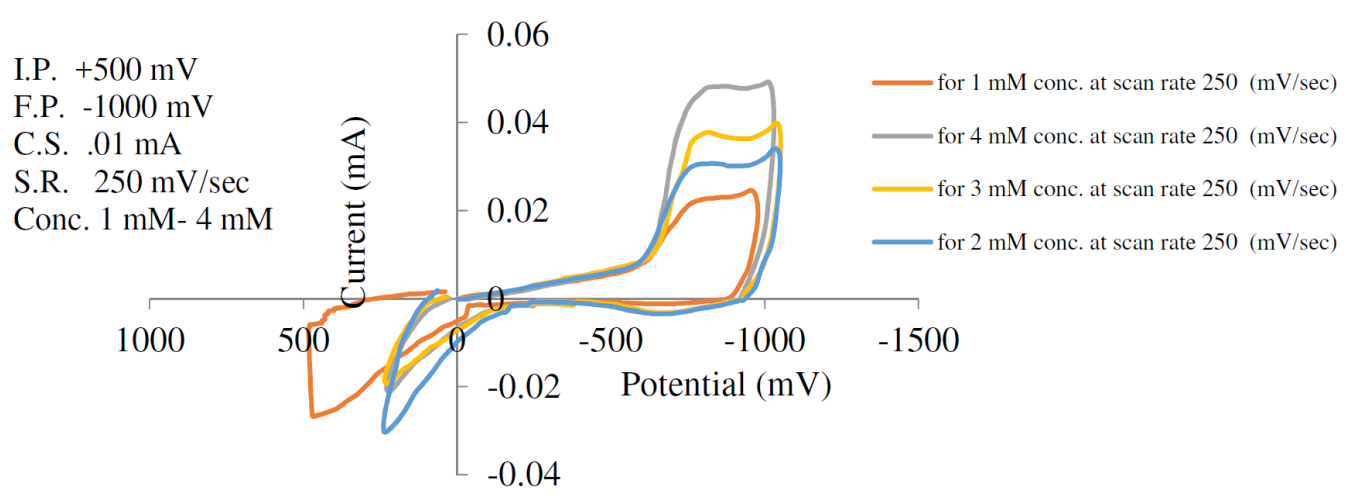

Figure 5. Cyclic voltammograms of the TBCHSC Co(II) complex in a methanolic medium with $1 \mathrm{mM}-4 \mathrm{mM}$ conc., at the scan rate of 250 .

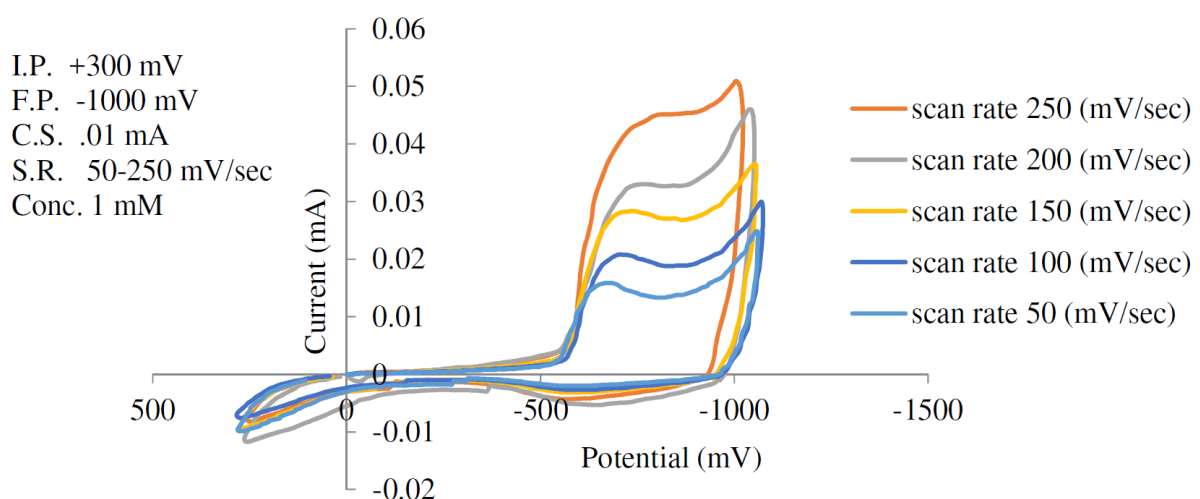

Figure 6. Cyclic voltammograms of the Co(II) complex of TBCHSC in a DMF medium with $1 \mathrm{mM}$ conc.

The cyclic voltammograms were recorded by varying the scan rate, keeping the $\mathrm{pH}$ and the solution concentration constant; the data exhibited one irreversible reduction peak at all scan rates. The peak potential value shifted towards the more negative direction, with an increase in the scan rate, indicating that the electrochemical process was irreversible (Fig. 8). The peak current was also increased as the scan rate increased for the compounds. The linear nature of the $\mathrm{I}_{\mathrm{pc}} \mathrm{v} / \mathrm{s} \mathrm{v}^{1 / 2}$ plot, with an intercept different of zero, showed that TBCHSC reduction was diffusion controlled (Fig. 7).

The concentration effect on the reduction potential was studied by varying the compound concentration from $1 \mathrm{mM}$ to $4 \mathrm{mM}$, keeping the scan rate constant. The cathodic peak current was found to linearly increase with an increase in the compound concentration. The plot of $\mathrm{I}_{\mathrm{pc}}$ vs. concentration showed linearity, further indicating that the electrode process was diffusion controlled. It was also observed that the peak potential $\left(\mathrm{E}_{\mathrm{pc}}\right)$ shifted towards more negative values, as the compound concentration increased (Table 4). This $\mathrm{E}_{\mathrm{pc}}$ shifts in the cathodic direction, with an increasing concentration, indicated that the reduction products were adsorbed onto the electrode surface; this kind of shift has been theoretically predicted and experimentally observed [29-30]. 


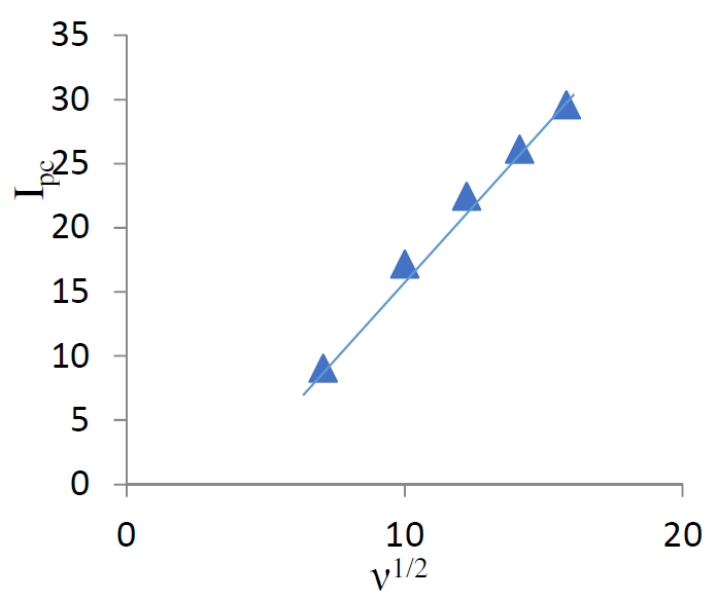

Figure 7. TBCHSC current $\left(\mathrm{I}_{\mathrm{pc}}\right)$ vs. $v^{1 / 2}$ in a methanolic medium containing phosphate buffer ( $\mathrm{pH} 8)$.

The $\mathrm{pH}$ effect upon TBCHSC reduction was investigated (Tables 1 to 3, and Fig. 8 ). The peak potential values of the compounds were found to change with the solution's $\mathrm{pH}$ value. This dependence of the peak potential on the $\mathrm{pH}$ indicates that the proton transfer took place during the electrode reaction. The peak potential shifts towards more negative values depended upon the solution's $\mathrm{pH}$. This meant that the reduction was easier in acidic media, and difficult in media where the proton concentration was low. The ease of reduction was found to be greater in an acidic $\mathrm{pH}$ than in an alkaline $\mathrm{pH}$, which might be because of the formation of an easily reducible protonated intermediate.

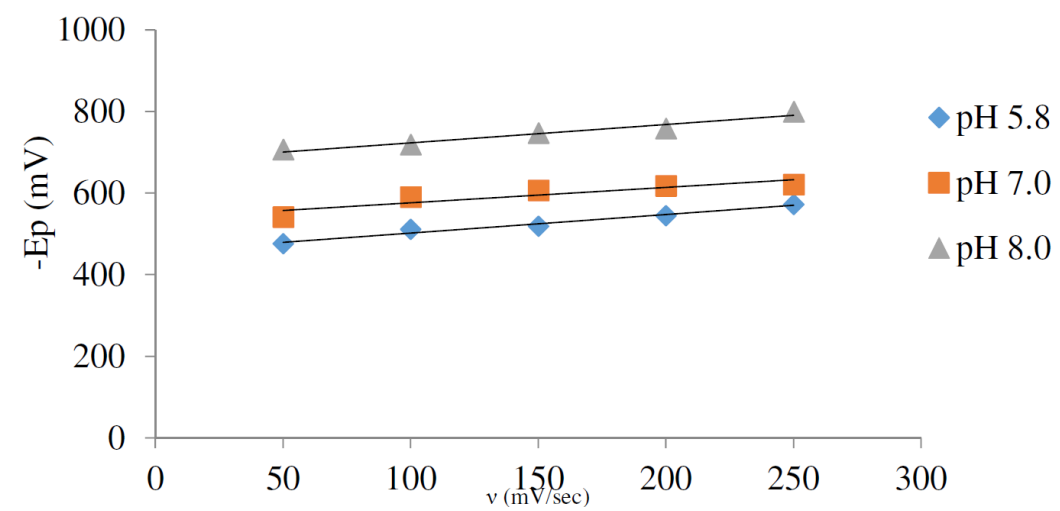

Figure 8. Potential vs. scan rate in a methanolic medium with a phosphate buffer ( $\mathrm{pH}$ $5.8,7$ and 8$)$.

Cyclic voltammograms were recorded in two different media: a DMF-phosphate buffer and a $\mathrm{CH}_{3} \mathrm{OH}$-phosphate buffer. It was observed that the peak potential shifted towards more negative values in the presence of an aprotic solvent (DMF), and the shift magnitude depended on the solvent nature. The shift order observed in the present study was DMF-phosphate $>\mathrm{CH}_{3} \mathrm{OH}$-phosphate buffer. This trend paralleled the trend observed in the solvent viscosity (DMF $0.796>$ methanol 0.544).

In this process, the imine group $(-\mathrm{C}=\mathrm{N}-)$ 4-tertbutylcyclohexanone semicarbazone was reduced into the amine group $\left(-\mathrm{CH}-\mathrm{NH}_{2}\right)$, in a protic solvent 
such as $\mathrm{CH}_{3} \mathrm{OH}$. Since all steps involved in the reaction mechanism took place at the same potential, it occurred a single reduction peak corresponding to the transfer of four electrons (Scheme III).

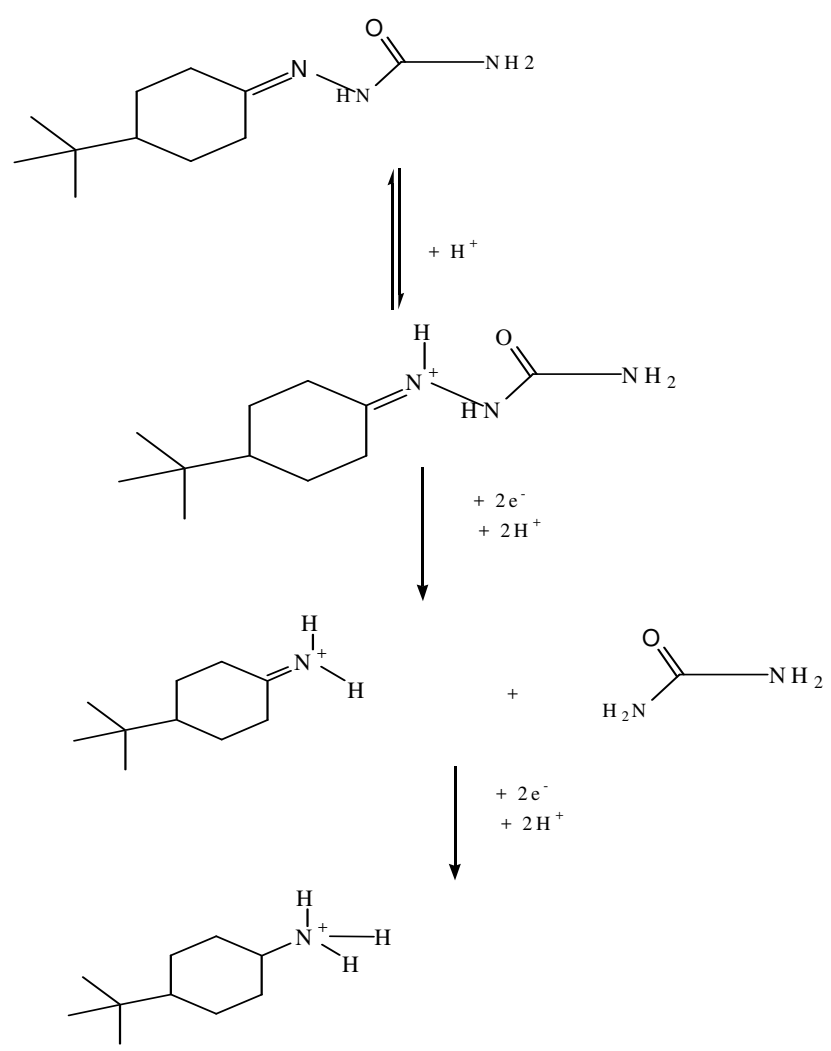

Scheme III. Proposed reduction mechanism for 4-tertbutylcyclohexanone semicarbazone.

In the case of the complex, no anodic peak appeared, indicating the irreversible nature of the electrode process [31]. The electrode nature was also confirmed from the peak potential value that shifted towards the more negative direction, with an increase in the scan rate. The peak current also increased as the scan rate increased for the compounds. The effect of the concentration on the reduction potential was studied by varying the compound concentration from $1 \mathrm{mM}$ to 4 $\mathrm{mM}$, keeping the scan rate constant. It was observed that the peak potential $\left(\mathrm{E}_{\mathrm{pc}}\right)$ shifted towards more negative values, and the cathodic peak current was found to linearly increase as the compound concentration increased. It was also observed that the peak potential shifted to more negative values in the presence of an aprotic solvent, and the shift magnitude depended on the solvent nature (Tables 5 to 6). If the reduction of the $\mathrm{Co}$ (II) complex and that of the ligand in alcoholic acidic $\mathrm{pH}$ were to be compared, it would be observed that the former would be more difficult than the latter, suggesting that the ligand reduction was proton dependant.

\section{Infrared study}

The absence of a $v(\mathrm{C}=\mathrm{O})$ band $\left(1745 \mathrm{~cm}^{-1}\right)$ of ketone, and the presence of a $v(\mathrm{C}=\mathrm{N})$ band occurred [32] at $1622-1632 \mathrm{~cm}^{-1}$ in the ligand spectra, indicated 
condensation between the ketonic group and the amino group of semicarbazide. In comparison with the semicarbazone spectra, the $\mathrm{Co}(\mathrm{II})$ complex exhibited the $v(\mathrm{C}=\mathrm{N})$ band in the $1590-1603 \mathrm{~cm}^{-1}$ region, showing the band shift to lower wave numbers, and indicating that the nitrogen was coordinated to the metal ion. The $v(C=O)$ band disappearance at $1700 \pm 100 \mathrm{~cm}^{-1}$ (initially present in the semicarbazone spectra), in the $\mathrm{Co}$ (II) complex spectra, indicated that the participation of ketonic oxygen resulted in a bond formation. The appearance of new bands in the 579-560 and 386-322 $\mathrm{cm}^{-1}$ regions assignable to $v_{\mathrm{M}-\mathrm{O}}$ and $\mathrm{v}_{\mathrm{M}-\mathrm{N}}$, respectively, reflected the bonding of the metal ions to oxygen and nitrogen atoms [33-36].

\section{Elemental analysis}

This section deals with the elemental (CHNO) analysis of the ligand and its complex (Table 7).

Table 7. Elemental analysis.

\begin{tabular}{|c|c|c|c|c|c|c|c|c|}
\hline \multirow[b]{2}{*}{$\begin{array}{l}\text { Sr. } \\
\text { No }\end{array}$} & \multirow[b]{2}{*}{ Specification } & \multirow[b]{2}{*}{$\begin{array}{c}\text { Colour } \\
\text { and state }\end{array}$} & \multicolumn{6}{|c|}{ Elemental analysis ( \%) } \\
\hline & & & $\begin{array}{c}\text { C } \\
\text { found } \\
\text { (calcd.) }\end{array}$ & $\begin{array}{c}\text { H } \\
\text { found } \\
\text { (calcd.) }\end{array}$ & $\begin{array}{c}\mathrm{N} \\
\text { found } \\
\text { (calcd.) }\end{array}$ & $\begin{array}{c}\text { O } \\
\text { found } \\
\text { (calcd.) }\end{array}$ & $\begin{array}{c}\text { Co } \\
\text { found } \\
\text { (calcd.) } \\
\end{array}$ & $\begin{array}{c}\text { M. Wt } \\
\text { found } \\
\text { (calcd.) }\end{array}$ \\
\hline 1 & $\begin{array}{l}\text { 4-terbutylcyclohexanone } \\
\text { semicarbazone } \\
\left(\mathrm{C}_{11} \mathrm{H}_{21} \mathrm{~N}_{3} \mathrm{O}\right)\end{array}$ & $\begin{array}{l}\text { Creamish } \\
\text { solid }\end{array}$ & $\begin{array}{c}62.52 \\
(62.87)\end{array}$ & $\begin{array}{c}10.02 \\
(10.51)\end{array}$ & $\begin{array}{l}19.89 \\
(20.05)\end{array}$ & $\begin{array}{c}7.57 \\
(7.89)\end{array}$ & 0 & $\begin{array}{c}211.30 \\
(212.46)\end{array}$ \\
\hline 2. & $\begin{array}{l}\text { 4-terbutylcyclohexanone } \\
\text { semicarbazone) } \\
\text { Co(II) complex } \\
\left(\mathrm{C}_{22} \mathrm{H}_{44} \mathrm{Co} \mathrm{N}_{6} \mathrm{O}_{4}\right)\end{array}$ & $\begin{array}{l}\text { Light } \\
\text { purple } \\
\text { solid }\end{array}$ & $\begin{array}{c}51.25 \\
(51.99)\end{array}$ & $\begin{array}{c}8.60 \\
(8.98)\end{array}$ & $\begin{array}{l}16.30 \\
(16.47)\end{array}$ & $\begin{array}{c}12.41 \\
(12.93)\end{array}$ & $\begin{array}{c}11.43 \\
(12.02)\end{array}$ & $\begin{array}{c}515.56 \\
(516.17)\end{array}$ \\
\hline
\end{tabular}

\section{Antimicrobial studies}

This section deals with the recent biological studies of semicarbazone and its cobalt(II) metal complex. The results of the antifungal study of TBCHSC and its Co(II) complex on Fusarium oxysporium, Trichoderma reesei (Table 8) and on Gram positive bacteria (Bacillus subtilis) and Gram negative bacteria (Escherichia coli) are recorded in Table 9. From Tables 8 to 9, it is clear that the inhibition was much larger for the metal complex than for semicarbazone.

Table 8. Antifungal studies of semicarbazone and its $\mathrm{Co}(\mathrm{II})$ complex.

\begin{tabular}{|c|c|c|c|c|c|c|c|c|}
\hline \multicolumn{4}{|c|}{ Fusarium oxysporium } & \multicolumn{4}{c|}{ Trichoderma reesei } \\
\hline $\begin{array}{c}\text { Anti- } \\
\text { fungal }\end{array}$ & \multicolumn{2}{|c|}{ TBCHSC } & \multicolumn{2}{c|}{ Co(II) complex } & \multicolumn{2}{c|}{ TBCHSC } & \multicolumn{2}{c|}{ Co(II) complex } \\
\hline $\begin{array}{c}\text { Stock } \\
\text { conc. } \\
\boldsymbol{\mu g} / \mathbf{m L}\end{array}$ & $\begin{array}{c}\text { Zone of } \\
\text { inhibition } \\
(\mathbf{m m})\end{array}$ & $\begin{array}{c}\text { Activity } \\
\text { index }\end{array}$ & $\begin{array}{c}\text { Zone of } \\
\text { inhibition } \\
(\mathbf{m m})\end{array}$ & $\begin{array}{c}\text { Activity } \\
\text { index }\end{array}$ & $\begin{array}{c}\text { Zone of } \\
\text { inhibition } \\
(\mathbf{m m})\end{array}$ & $\begin{array}{c}\text { Activity } \\
\text { index }\end{array}$ & $\begin{array}{c}\text { Zone of } \\
\text { inhibition } \\
(\mathbf{m m})\end{array}$ & $\begin{array}{c}\text { Activity } \\
\text { index }\end{array}$ \\
\hline 20 & 07 & 0.31 & 14 & 0.636 & 15 & 0.68 & 19 & 0.86 \\
\hline 40 & 20 & 0.90 & 19 & 0.863 & 15 & 0.68 & 18 & 0.81 \\
\hline 60 & 20 & 0.90 & 30 & 1.360 & 16 & 0.72 & 22 & 1.00 \\
\hline 80 & 24 & 1.09 & 20 & 0.900 & 35 & 1.59 & 22 & 1.00 \\
\hline
\end{tabular}


Table 9. Antibacterial studies of semicarbazone and its Co(II) complex.

\begin{tabular}{|c|c|c|c|c|c|c|c|c|}
\hline \multicolumn{5}{|c|}{ Bacillus subtilis } & \multicolumn{4}{c|}{ Escherichia coli } \\
\hline $\begin{array}{c}\text { Anti- } \\
\text { bacterial }\end{array}$ & \multicolumn{2}{|c|}{ TBCHSC } & \multicolumn{2}{|c|}{ Co(II) complex } & \multicolumn{2}{c|}{ TBCHSC } & \multicolumn{2}{c|}{ Co(II) complex } \\
\hline $\begin{array}{c}\text { Stock } \\
\text { conc. } \\
\boldsymbol{\mu g} / \mathbf{m L}\end{array}$ & $\begin{array}{c}\text { Zone of } \\
\text { inhibition } \\
(\mathbf{m m})\end{array}$ & $\begin{array}{c}\text { Activity } \\
\text { index }\end{array}$ & $\begin{array}{c}\text { Zone of } \\
\text { inhibition } \\
(\mathbf{m m})\end{array}$ & $\begin{array}{c}\text { Activity } \\
\text { index }\end{array}$ & $\begin{array}{c}\text { Zone of } \\
\text { inhibition } \\
(\mathbf{m m})\end{array}$ & $\begin{array}{c}\text { Activity } \\
\text { index }\end{array}$ & $\begin{array}{c}\text { Zone of } \\
\text { inhibition } \\
(\mathbf{m m})\end{array}$ & $\begin{array}{c}\text { Activity } \\
\text { index }\end{array}$ \\
\hline 20 & 05 & 0.25 & 16 & 0.8 & 04 & 0.20 & 08 & 0.40 \\
\hline 40 & 09 & 0.45 & 12 & 0.6 & 03 & 0.15 & 04 & 0.20 \\
\hline 60 & 12 & 0.60 & 14 & 0.7 & 03 & 0.15 & 04 & 0.20 \\
\hline 80 & 15 & 0.75 & 16 & 0.8 & 09 & 0.45 & 10 & 0.50 \\
\hline
\end{tabular}

\section{Conclusion}

From the electrochemical studies, it was concluded that the semicarbazone reduction and its $\mathrm{Co}$ (II) complex is irreversible. Keeping in view the feasibility of the reduction site, and on the basis of cyclic voltammetric results, the reduction mechanism shown in the Scheme III may be suggested for the electro reduction of 4-tertbutylcyclohexanone semicarbazones, similar to that reported in the literature [21-24]. The mechanism finds support from the $\mathrm{E}_{\mathrm{pc}}$ and $\mathrm{E}_{\mathrm{p} 1 / 2}$ shifts towards the negative potential, with $\mathrm{pH}$, as protons are consumed in the reduction. The antimicrobial activity of the complex is higher in comparison to semicarbazone, which indicates that metallation increases biological activity.

\section{Acknowledgements}

Authors thank the Head of the Department of Chemistry for providing the necessary laboratory facilities. Ms. Lakshmi Meena is thankful to CSIR, New Delhi, for financial assistance.

\section{References}

1. Mamatha GP, Sherigara BS, Mahadevan KM. Indian J Chem Tech. 2007; 14: 566-571.

2. Jayadevappa H, Shivraj Y, Mahadevan KM, et al. Indian J Chem Tech. 2006; 13: 269-277.

3. Zuman P, Barns B, Rovolova A. Discuss Faraday Soc. 1968; 45: 202.

4. Schultz HP, Popp FD. Chem Rev. 1962; 62: 19-40.

5. Garcia-Tojal J, Lezama L, Pizarro JL, et al. Polyhedron. 1999; 18: 3703.

6. Mishra D, Naskar S, Drew MGB, et al. Inorg Chimica Acta. 2006; 359: 585.

7. Mulleiz E, Fontecave M. Coord Chem Rev. 1999; 185: 775.

8. Perez-Rebolledo A, Piro OE, Castellano EE, et al. J Mol Struct. 2006; 794: 18.

9. Casas JS, Garcia-Tasende MS, Sordo J. Coord Chem Rev. 2000; 209: 197.

10. Goyal RN, Minocha A. J Indian Chem Soc. 1985; 62: 202.

11. Sangtyani R, Kumar V, Meena RC, et al. Int J Chem Tech Res. 2012; 4: 180. 
12. Mishra AK, Gode KD. Analyst. 1985; 110: 1373.

13. Reddy BB, Sreedhar NY, Reddy SJ. Indian J Chem. 1991; 30A: 119.

14. Kumar BGK, Sankar TR, Ramana PV, et al. Bull Electrochem. 2006; 22: 269.

15. Pessoa MMB, Andrade GFS, Santos MR, et al. J Electroanal Chem. 2003; 545: 117.

16. Kitaev YuP, Budnikov GK, Troepol'skaya TV, et al. Zhurnal Obshchei Khimii. 1967; 37: 1437.

17. Lund H. Acta Chem Scand. 1959; 13: 249.

18. Soucaze-Guillous B, Lund H. J Electroanal Chem. 1997; 423: 109.

19. Sangtyani R, Rawat J, Verma PS, et al. J Indian Chem Soc. 2011; 88: 1553.

20. Reddy KH, Reddy PS, Babu PR. Transit Met Chem. 2000; 25: 154.

21. Sharma P, Kumar A, Sharma M. Indian J Chem. 2006; 45A: 872.

22. Bard AJ, Faulkner LR. Electrochemical Methods, Fundamentals and Applications. New York:Wiley; 1980.

23. Choudhary P, Sharma A, Varshney AK, e al. J Indian Chem Soc. 2017; 94: 613-622.

24. Noel M, Vasu KI. Cyclic Voltammetry and the Frontiers of Electrochemistry. New Delhi: Oxford and IBH Publishing Co Pvt Ltd; 1990.

25. Kamal R, Elixir Appl Botany. 2012; 46: 8487-8489.

26. Ashokvardhan T, Rajithasri AB, Prathyusha P, et al. Int J Curr Microbiol App Sci. 2014; 3(4): 894-903.

27. Tangh HA, Wang LF, Yang RD. Transit Met Chem. 2003; 28: 395-398.

28. Costa RFF, Rebolledo AP, Matencio T. J Coord Chem. 2005; 58: 1307-1319.

29. Nicholson RS, Shain I. Anal Chem. 1994; 36: 722.

30. Adam RN. Electrochemistry at Solid Electrodes. New York: Marcel Dekker; 1996.

31. Kulkarni AD, Patil SA, Badami PS. Int J Electrochem Sci. 2009; 4: 717.

32. Noel M, Anantharaman PN. Analyst. 1985; 110: 1095.

33. Hassaan AMA. Indian J Chem. 1997; 36: 241-243.

34. Soliman AA, Linert W. Thermochim Acta. 1999; 333: 67-75.

35. Nakamoto K. Infrared Spectra of Inorganic and Coordination Compounds. NewYork: Wiley-Interscience; 1970.

36. Yadav HS, Sihag S, Varshney AK, et al. J Indian Chem Soc. 2015; 92: 13291336. 